\title{
People Empowerment Strategy at Human Primordial Conservation Zone of Sangiran, Sragen Regency
}

\author{
Dewi Rostyaningsih ${ }^{1}$, Hesti Lestari ${ }^{2}$ \\ \{dewi_sabowo@yahoo.co.id ${ }^{1}$, hestilestari1959@gmail.com\} \\ Universitas Diponegoro, Indonesia ${ }^{1,2}$
}

\begin{abstract}
Sangiran Site in Sragen Regency is an ancient life site becoming a world heritage which has the potential as a tourism site. It is located on lands owned by local residents. The government cooperates with the residents to protect it, if the residents do their activities/farming, theywill not damage it. Its existence is expected to improve people's welfare. The government's effort to improve the people's welfare is conducted through people empowerment, especially in tourism sector. In the context of people empowerment, it would be more appropriate if it was carried out on business actors, especially those who are engaging in the field of tourism. In connection with such matter, strategy of people empowerment can be carried out through 5 (five) programs: 1) Human resource development: socialization, workshops and trainings; 2) Groupinstitutions development; 3) Collection of people capital; 4) Innovative productive businesses development, and 5) Provision of appropriate information; tour packages development. Conclusion: Sangiran as a tourism site has not prospered the local people. People empowerment strategies are needed in order to make them participate in the tourism sector. Suggestion: commitment from central and regional government in empowering the peoplein order to achievewelfare.
\end{abstract}

Keywords: Strategy, People Empowerment, Government Commitment.

\section{Introduction}

Sangiran site is a tourism area in Sragen Regency. It is stretches over approximately 56 square $\mathrm{km}$ area on arid land. This land is legaly owned by the local residents. In 1996, the Sangiran Site was designated as a World Heritage by UNESCO named Sangiran The Early Man Site. Sangiran tourism object is a museum having functioned as a place to develop science, education and tourism. Inside the museum, ancient relics can be found including human artifacts, flora and fauna, as well as household appliances, thus attracting tourists to visit. The museum has four clusters located in Sragen Regency, namely Krikilan Cluster (the largest cluster), Bukuran Cluster, Ngebung Cluster and Manyarejo Cluster, alsoa cluster located in Karanganyar Regency, Dayu Cluster.

This area has several positive potentials such as rice and field products, traditional arts (Lesung, Lengger, Gambyong, Tari Purba, Jathilan, Bubat Kawah and Klothekan), traditional medicine using "balung buto", home industries such as batik, gloyor sarong, coconut shell buttons, and stones crafting. There can also be found other tourism products such as saltwater tours (barklay), souvenir shops, homestays and there are already 25 residents who have certificates as tour guides. 
There are several problems of Sangiran Site inter aliathe poor residents, low education levels, simple housing conditions. If there is a house that looks better than other general houses, it is the result of remittances from their family who migrated to other areas. On the other hand, a problem also arises is the lack of harmonious relations between Tourism Awareness Group (Kelompok Sadar Wisata/Pokdarwis) and village apparatus. It often happens when activities related to tourism, the Tourism Awareness Group is not involved by village apparatus. They only involve their own people. For example, for activities in the souvenir sales sector, it is controlled by a family and their descendants, not involving the whole community. Conflicts of interest relating to the management of parking lots which are customary village landsshould empower the community, but it has not been done. The lack of road infrastructure to the Ngebung, Bukuran and Manyarejo Clusters so that Buses cannot enter. Tourists tend to only visit the Krikilan Cluster because of the transportation problems. Governments are passing responsibilities between provinces and districts. The existence of the museum is expected to absorb workforce from the local people. If there are any local people become workers in the museum, they only become menial staffs, such as cleaning services and security guards. Most of the workers are from outside the area.

The funds disbursed to Sangiran have not been enjoyed by the local people, they are only as spectators. Seeing the above conditions, in order to develop the tourism at the Sangiran Site, the government collaborates with the local people to preserve the Site. If people do their activities and grow crops and discover ancient objects, they can participate in guarding the objects by submitting the discovery to the museum.

The main objective of tourism development is to be able to integrate all aspects of tourism development with the local people socio-economic life [1]. The local people are the main goal in a tourism development. The integration between the development of tourism with the lives of local people will present various benefits including increasing welfare, opening new jobs, developing local economies [1].

Head of the Center for Preservation of Primordial Human Sites (CPPS), Hidayat said that he could not optimally develop the Sangiran Fossil Museum [2]. Yet we know that the existence of tourism can have a positive impact on improving the welfare of the Sangiranpeople. Therefore, the government's steps to increase the welfare of society can be done through people empowerment, especially in the field of tourism.

\section{Research Method}

This research uses qualitative research methods, namely research used to examine natural subjects and researchers as a key element [3]. Data collection was obtained through observation and in-depth interviews with snowballing techniques. The research subjects were Subur, Sudarmi, and Karyadi, they were chairmen, treasurers and members of the Tourism Awareness Group; Suratmo, Homestay owner and community leader (son of Toto Marsono, the pioneer of Sangiran museum); Sumini, the food seller; Tukinah, Sumiati, Titik, the batik artist from Bukuran village; Heriyanto, a craftsman in Bukuran village, and Josep, Head of the Sragen Regency Tourism and Sports Office. The data analysis technique in this study used an interactive model of Miles and Huberman consisting of data reduction, data presentation and making conclusions. 


\section{Literature Review}

\subsection{People Empowerment Strategy}

Conceptually, empowerment comes from the word "power". The main idea of empowerment is in related with the concept of power. Several definitions of empowerment can be seen from the objectives, processes and ways of empowerment [4]:

a) Empowerment aims to increase the power of people who are weak and disadvantaged (Ife, 1995).

b) Empowerment is a process in which people become strong enough to participate in various top controls, and influence on, events and institutions that affect their lives. Empowerment emphasizes that people obtain sufficient planning, knowledge and power to influence their lives and the lives of others who are in their concern (Parson et al, 1994).

c) Empowerment is a way by which people, organizations and communities are directed to be able to master (have power over their lives) (Rappaport, 1984).

Empowerment as a process is a series of activities to strengthen the power or empowerment of weak groups in society [4]. The process of people empowerment is the granting of authority and giving of people capacity. These two elements can not be separated $[5]$.

People empowerment activities are activities which have clear objectives and must be achieved, each implementation of community empowerment needs to be based on certain work strategies for its success to achieve the desired goals. In everyday terms, strategy is often interpreted as certain steps or actions carried out in order to achieve a desired goal or beneficiary [6].

The strategy of people empowerment basically has three directions [6]:

a) Siding and empowering the people.

b) Strengthening autonomy and delegating authority in the management of development that develops people participation.

c) Modernization through sharpening the direction of change in the socio-economic, cultural and political structure which is based on people participation.

In this connection, Ismawan [6] determined that there are 5 (five) empowerment strategy programs consisting of:

a) Human resource development.

b) Development of group institutions.

c) Collection of community capital.

d) Development of productive business.

e) Provision of appropriate information.

\subsection{Tourism}

According to the WTO (World Tourism Organization) defines tourism as the activities of people who travel to and live in places outside their usual environment for no more than one year in a row for vacation, business and other destinations [7].

According to Law Number 10/2019 on Tourism, "Tourism” is defined as: “... overall activities related to tourism and are multidimensional and multidisciplinary in nature that emerge as a manifestation of the needs of each person and the State as well as interactions 
between tourists and the local people, fellow tourists, the government, LocalGovernments and Entrepreneurs".

Tourism products are goods and services that are enjoyed or consumed directly by tourists regarding their tourism needs. Tourism Products can be grouped into two, namely [7]:

a) Goods: a) general tourist destinations; b) products for consumption; foods and drinks; c) tourism memories in the form of souvenirs.

b) Services: a) lodging services, including hotel services and other accommodations; b) transportation services, including aerospace, sea and land vehicle services, transportation connections services and transportation provision services or travel management companies; c) soul refreshment services, including music; dance; spa, karaoke.

Based on the above opinion it can be concluded that tourism is an activity related to people who travel so that there is an interaction between tourists and the local people, fellow tourists, the government, local government and entrepreneurs. Empowerment strategies in the field of tourism can be done by involving local people in activities related to tourism products in the form of goods and services.

\section{Result and Discussion}

Sangiran tourism potential is possible to be developed considering that Sangiran is a World Heritage. To prosper the Sangiranpeople, it needs to be a people empowerment so that they are able to get involved in the tourism activities. The people can be involved in providing tourism products in the form of goods and services. Goods products in the form of food and beverages for consumption also souvenirs, while service products can be in the form of lodging services, transportation services, and soul freshness services.

Based on the research results, the People Empowerment Strategies at Sangiran Site are as follows:

\subsection{Human Resources Development}

People empowerment efforts that have been carried out by the local government are coaching to produce quality souvenirs that have the characteristics of Sangiran and foster traditional arts, homestay management, and provision of local guides in Sangiran.

Further said by Amirul et al, [8] that the training conducted at Sangiran included:

a) Souvenir Making Training: This activity was held on April 21-23, 2015 at the CPPS Sangiran Seminar Room by presenting speakers from the ISI Surakarta and attended by 25 local people. It aims to foster new creativity for the local people;

b) Homestay Management Training: homestay management training activities with the aim that local people have broad insights to be able to take advantage of the increasing number of visitors in the museum, and be able to take advantage of existing opportunities. This activity was held on August 26-28, 2015, with 25 participants;

c) Local Guides Training: This activity was held on December 02-04, 2015 presenting speakers from the Yogyakarta branch of the Indonesian Tour Guide Association and attended by 25 people. Next isthe effort to increase the number of people who get the Guide Certification.

The above activities need to be followed up with other training activities to meet the needs of goods and services on the Sangiran Site. The government can also establish 
cooperation with related agencies. Besides training, it is also necessary to conduct a comparative study to tourism sites that have a developed tourism potential both in the country and abroad. In addition to conducting training, the government together with the local people visited Philippines for a comparative study of tourism management.

\subsection{Development of Group Institutions}

The groups that need to be developed in Sangiran [9] are:

a) Art Group to support attractions that will be showed during important moments and welcoming guests.

b) Direct Service Group consisting of: a) Tour guide groups by deepening their knowledge of ancient relics, English language skills and services to tourists, b) Security groups through site security management, c) Hygiene group to maintain environmental hygiene, d) Restaurant business group, e) Lodging business group, f) Transportation business groups.

c) Small and Medium Business Group of Handicrat, including: a) Craftsmen of plaited rock, b) Bamboo woven craftsmen, c) Wood craftsman, d) Coconut shell craftsmen, e) Batik craftsmen. Each group can be empowered according to their expertise, in this case the government can work together with the parties involved in the empowerment both in the manufacturing process, packaging and marketing.

d) The Livestock and Fisheries Business Group is empowered through capital collection, skills and cooperative formation.

e) Agricultural Business Group, is empowered through the formation of associations, the provision of superior seeds and the formation of cooperatives.

\subsection{The Collection of People Capital}

Along with institutional strengthening marked by the formation of groups in the local people, capital collection can be done through membership fees from both the Arts Group, the Direct Service Group, the Small and Medium Business Group of Handicraft (batik, stone, wood, bamboo), the Livestock and Fisheries BusinessGroup and Agricultural Business Group, then endeavored to form cooperatives that can support the capital of group members through savings and loan activities.

\subsection{Development of Productive Business}

The development of productive business can be carried out by the production groups in Sangiran, but the problem is how to market the results of the production business. In order to intensify tourism in Sangiran, according to the head of the Department of Youth Sports and Tourism, Sragen Regency will hold: 1) Culinary festivals; 2) Art festivals and 3) Coffee festivals which will be held in 2020. In the preparation of this activity, facilities and infrastructure must be well prepared such as homestay preparations both government and community-owned, making gazebos, and others. Therefore, this activity involves the government, entrepreneurs, the community and other stakeholders. The implementation of such activities must take place continuously in the upcoming years. Through this activity the local people participate in productive business so that the results can prosper them. 


\subsection{Provision of appropriate information}

Center for Preservation of Primordial Human Sites (CPPS) The Directorate General of Culture, Ministry of Education and Culture in collaboration with UNESCO has collaborated to provide information in the form of books, brochures, leafleats and websites about the Sangiran museum which inform the five clusters namely the Krikilan Cluster (the biggest cluster); Ngebung Cluster, Bukuran Cluster, Manyarejo Cluster and Dayu Cluster (including Karanganyar Regency). The information that needs to be developed is the existence of tour packages associated with Solo Raya Tourism packages, so Sangiran becomes a tourist destination along with visits to Solo, Gunung Sewu, Tawangmangu, Waduk Gajah Mungkur, etcetera.

Five Sangiran people empowerment strategies in the field of tourism, the first to the third strategy, namely the development of human resources, the development of group institutions and the collection of people capital have been carried out, although has not been maximum, but for productive business development strategies and the provision of appropriate information, need serious attention if we want to develop Tourism in Sangiran. In connection with those facts, Usman (2010) states that:

"Regional development is actually not merely a duplication of national development. Regional development is also not only a smaller form of national development plan. Regional development has its own or character, and has a pattern and spirit that is in accordance with its conditions and potential".

The government must have a grand design about Sangiran where this will be taken. GanjarPranowo, the current governor of Central Java, wants to make Sangiran a unique destination, for example ancient-themed cartoons such as The Flinstones or Jurassic Park. The five people empowerment strategies in the field of tourism need to be taken seriously. Sragen Regency as an area where Sangiran site is located cannot work alone in developing tourism. To make Sangiran a national and international tourist destination surely requires the intervention of all parties, both the central, provincial and district governments.

Thus, planning and implementation of regional development is quite complex, considering that besides being able to accommodate the national interests in the area, but also the ability to identify and channel aspirations in the regions.

\section{Conclusion}

Sangiran as a World Heritage site has not prospered the people. The government needs to implement people empowerment strategies in the tourism sector which includes:

a) Human resource development, carried out through trainings, certified training and comparative studies.

b) Institutional group development by organizing a program of activities suitable for the Arts Group, the Direct Service Group, the Small and Medium Business Group of Handicraft, the Livestock and Fisheries Business Group and the Agricultural Business Group.

c) Collection of people capital is conducted through the formation of cooperatives derived from membership fees. 
d) Development of productive businesses: the people is involved in participating in festivals through the results of their products in the form of goods or services.

e) Providing appropriate information through books, brochures, leaflets, websites that can promote Sangiran Site tourism and Sangiran linkages with other tourist destinations.

The People Empowerment Strategies in tourism atSangiran Site still needs to be improved considering that Sangiran as a World Heritage is worthy of being a national and international tourist destination. The urgent thing to do is determine the grand design of the Sangiran Site. Recommendation: commitment from the central and regional government in developing tourism and empowering the local people to make properous.

\section{References}

[1] M. M. Afandi, Rois Lukman; Ali, "Kajian Pengaruh Keberadaan Kawasan Wisata Sangiran Terhadap Aspek Fisik, Aspek Ekonomi, Dan Aspek Sosial Masyarakat,” Tek. Perenc. Wil. Kota, vol. 4, no. 2, pp. 282-292, 2015.

[2] Tempo, "Mencari Solusi Sangiran Jadi Destinasi Wisata Dunia," October, 2019. .

[3] Sugiyono, Metode Penelitian Kuantitatif, Kualitatif dan R\&D. Bandung: Alfabeta, 2008.

[4] E. Suharto, MembangunMasyarakatmemberdayakan Rakyat, Kajian Strategis Pembangunan kesejahteraan Sosial \& Pekerja Sosial. Bandung: PT Refika Aditama, 2017.

[5] Soetomo, Pemberdayaan Masyarakat, Mungkinkah Muncul Antitesisnya? Yogyakarta: Pustaka Pelajar, 2011.

[6] T. Mardikanto and P. Soebiato, "Pemberdayaan masyarakat dalam perspektif kebijakan publik," 2012.

[7] R. Nugroho, KebijakanPariwisata, SebuahPengantarUntuk Negara Berkembang. Yogyakarta: Pustaka Pelajar, 2018.

[8] M. A. Huda, "Persepsi dan Partisipasi Publik dalam Upaya Pemanfaatan Museum Situs Sangiran Berbasis Masyarakat," Humanis, vol. 19, no. 1.

[9] B. Sulistyanto, "Pemberdayaan Masyarakat di Lingkungan Cagar Budaya Situs Sangiran," Kehidup. Purba Sangiran, pp. 119-136, 2011. 